\title{
Modeling the effects of light wavelength on the growth of Nostoc ellipsosporum
}

\author{
Martha-Lucía Ortiz-Moreno ${ }^{1, *}$, Jaleydi Cárdenas-Poblador ${ }^{2}$, Julián Agredo ${ }^{3}$, \\ Laura-Vanessa Solarte-Murillo $^{4}$
}

\begin{abstract}
Edited by
Juan Carlos Salcedo-Reyes

(salcedo.juan@javeriana.edu.co)

1. Universidad de los Llanos,

Faculty of Basic Sciences and Engineering, Department of Biology and Chemistry, Biorinoquia and SUSA Groups, Km 12 Highway Villavicencio - Puerto López, Villavicencio - Colombia, zip code 1745.

2. Universidad de los Llanos,

Faculty of Basic Sciences and Engineering, Department of Mathematics and Physics, Sistemas Dinámicos Group, Km 12 Highway Villavicencio - Puerto López, Villavicencio - Colombia, zip code 1745.

3. Escuela Colombiana de Ingeniería Julio Garavito, Department of Mathematics, GIMATH (Grupo de investigación en Matemáticas de la Escuela Colombiana de Ingeniería) Group, Autopista Norte AK 45 No. 205-59, Bogotá - Colombia, zip code 111166.

4. Universidad de los Llanos,

Faculty of Basic Sciences and Engineering, Department of Biology and Chemistry, Biorinoquia Group, Km 12 Highway Villavicencio - Puerto López,

Villavicencio - Colombia, zip code 1745.

*mlortiz@unillanos.edu.co
\end{abstract}

Received: 01-06-2018

Accepted: 29-08-2019

Published on line: 04-05-2020

\begin{abstract}
Mathematical models provide information about population dynamics under different conditions. In the study, four models were evaluated and employed to describe the growth kinetics of Nostoc ellipsosporum with different light wavelengths: Baranyi-Roberts, Modified Gompertz, Modified Logistic, and Richards. N. ellipsosporum was grown in BG-11 liquid medium for 9 days, using 12 hours of photoperiod and the following treatments: white light $(400-800 \mathrm{~nm})$, red light $(650-800 \mathrm{~nm})$, yellow light $(550-580 \mathrm{~nm})$ and blue light $(460-480 \mathrm{~nm})$. Each experiment was performed in triplicate. The optical density (OD) was measured on days 1, 3, 5, 7 and 9, using a spectrophotometer at $650 \mathrm{~nm}$. The maximum cell growth was obtained under white light $\left(O D_{650}: 0.090 \pm 0.008\right)$, followed by the yellow light $\left(O D_{650}: 0.057 \pm 0.004\right)$. Conversely, blue light showed a marked inhibitory effect on the growth of $N$. ellipsosporum $\left(O D_{650}: 0.009 \pm 0.001\right)$. The results revealed that the Baranyi-Roberts model had a better fit with the experimental data from $N$. ellipsosporum growth in all four treatments. The findings from this modeling study could be used in several biotechnological applications that require the production of $N$. ellipsosporum and its bioproducts.
\end{abstract}

Keywords: cyanobacteria; light; mathematical model; microbial growth.

\section{Introduction}

Cyanobacteria are gram-negative prokaryotes that represent the oldest group of autophototrophic organisms able to perform oxygenic photosynthesis (Makhalanyane et al., 2015).They have an evolutionary history of 3.5 billion years and are the ancestors of all plastids. They also serve as the only source of biogenic oxygen and a major source of fixed carbon and nitrogen (Pang et al., 2018). These microalgae are widely distributed in aquatic and terrestrial niches, this dominance is due to their metabolism, plasticity and structural conservation (Abed et al., 2009). Cyanobacteria are known for 
Citation: Ortiz-Moreno ML, CárdenasPoblador J, Agredo J, Solarte-Murillo LV. Modeling the effects of light wavelength on the growth of Nostoc ellipsosporum, Universitas Scientiarum, 25 (1): 113-148, 2020. doi: 10.11144/Javeriana.SC25-1.mteo

Funding:

Universidad de los Llanos and COLCIENCIAS grant 497

Electronic supplementary material: N.A.

OPEN ACCESS their complex photosynthetic systems, which can channel the absorbed solar energy into diverse forms of energy along with producing several metabolic products with biotechnological applications, such as proteins, exopolysaccharides (EPS), pigments, lipids for third generation biofuels, biofilters, antioxidants, biofertilizers and others (Delattre et al., 2016; Guo et al., 2016; Margarites et al., 2016; Pereyra \& Ferrari, 2016; Ryu et al., 2017; Garlapati et al., 2019).

Among the cyanobacteria, the species from the genus Nostoc stand out as ideal candidates for biopharmaceutical applications (Cibichakravarthy et al., 2019). There are over 40 different Nostoc species that produce more than 120 bioproducts with antiviral, antioxidant, anticancer, antifungal and antimicrobial activities (Shalaby et al., 2019). These species are found in gelatinous colonies, composed of filaments called "trichomes"surrounded by a thin mucilaginous sheath that excrete EPS, which released is mainly concerned with protecting cells from physical or chemical stress and for anchorage purposes (Garlapati et al., 2019). They are known for their ability to lie dormant for long periods of time and recover metabolic activity when rehydrated with water (Nostoc ellipsosporum, 2018). The present study focuses in Nostoc ellipsosporum, a species known for its unusual chemicophysical stability with a prospective role in metallic nanoparticles production (Khanna et al., 2019), and its potent virucidal activity against a broad spectrum of enveloped viruses, including human immunodeficiency virus (HIV), influenza virus and herpes simplex virus, thanks to the cyanovirin-N protein produced by this microorganism (Xiong et al., 2010; Singh et al., 2017). Due to the type of applications, $N$. ellipsosporum requires innocuous culture conditions in order to avoid contamination, and axenic conditions to ensure the dominance of the species. Therefore, large-scale microalgae cultivation systems, such as open raceway ponds, are not suitable for this species, because they often suffer losses in productivity or alterations in the biochemical production as a result of contamination by parasites, predators or competitor microalgae that could inhibit the growth of $N$. ellipsosporum (Fuentes et al., 2016; McBride et al., 2016; Novoveska et al., 2016; Supriyanto et al., 2019).

A crucial point in the biotechnological process of Nostoc is to identify the optimal growth conditions that result in higher biomass accumulation, and improvement of polysaccharide production and structural features (Chiu et al., 2008; Da Silva Ferreira \& Sant'anna, 2017). Hence, an increasing number of researchers are focusing on how to increase cyanobacterial bioproducts yields by optimizing specific culture conditions, such as light, $\mathrm{pH}$, carbon source and nitrogen source (Andersen, 2005; Xu et al., 2019). This is closely linked to the species physiology and the requirements of each growth 
phase, lag and exponential (Crnkovic et al., 2017; Cui et al., 2017). Cellular division during these growth phases depends on light and nutrient availability, as those are vital for the photosynthetic system (Barsanti \& Gualtieri, 2006; Celekli et al., 2009; De Oliveira et al., 2014; Crnkovic et al., 2017). During this photosynthetic process, the sunlight is trapped by the pigments stored in the multilaminar complex named thylakoids and then elated to the core of photosystems I and II (Nozzi et al., 2013).

Cyanobacterial photosystems are mainly composed by chlorophyll a, which maximum absorption wavelength is $420 \mathrm{~nm}$, and phycobiliproteins, such as phycocyanin and phycoerythrin, that absorb light at $610 \mathrm{~nm}$ and $570 \mathrm{~nm}$, respectively (Barsanti \& Gualtieri, 2006). Visible light or white light contains all wavelengths from about $400 \mathrm{~nm}$ to $800 \mathrm{~nm}$. Thus, white light is able to stimulate all the photosynthetic pigments from photoautotrophic organisms (Hai et al., 2000). However, in terms of light quality, it has been shown that different wavelengths can enhance the sustainability of cyanobacteria cultures according to the target of production (Pagels et al., 2019). For instance, multiple studies reported that red light $(650 \mathrm{~nm})$ and blue light could promote the production of EPS or accelerate metabolic paths in cyanobacteria from genera Nostoc, Synechocystis and Synechococcus (Bland \& Angenent, 2016; Han et al., 2017a; Han et al., 2017b; Ooms et al., 2017), and the microalgae Chlorella (Atta et al., 2013).

Overall, the growth, survival, and production of cyanobacteria bioproducts have been shown to be affected by some abiotic factors such as different light wavelength bands (Sinha et al., 2003). Thus, there is a need for evaluating the different light wavelengths that may affect the growth and synthesis of bioactive compounds in order to commercially exploit Nostoc ellipsosporum (Kokabi et al., 2019). This type of research signifies an inexpensive alternative to enhance biomass production without increasing the nutrient supply (Johnson et al., 2014; Han et al., 2015; Khajepour et al., 2015; Gaytán-Luna et al., 2016; Crnkovic et al., 2017; Da Silva Ferreira \& Sant'anna, 2017).

Microalgae growth can be monitored employing the linear relationship between optical density (OD) and cell density during the exponential phase (Griffiths et al., 2011; Liu et al., 2011), provided by the direct correlation between OD and the concentration of photosynthetic pigments like chlorophyll and phycobiliproteins (Richmond, 2004; Algal culturing techniques, 2005; Delattre et al., 2016). Therefore, microbial biomass and microbial pigments can be estimated by measuring absorption at certain wavelength (Da Silva Ferreira \& Sant'anna, 2017). The results can be used to analyze the effect of environmental variables on microalgae growth at 
different scales (Chiu et al., 2008; Ryu et al., 2017). Once the variables affecting the microalgae physiology are understood, growth can be mathematically modeled (Halmi et al., 2014; Park \& Lee, 2016; Lotfi et al., 2017). This approach has been used in monitoring the growth of Chlorella vulgaris (Infante et al., 2012), Spirulina platensis (Kim \& Lee, 2018), and Synechocystis sp (Schuurmans et al., 2017).

A typical microbial growth curve shows sigmoidal behavior and exhibits four growth phases (lag, exponential, stationary, and cell death). During the lag phase, microorganism adapt to culture conditions. Through the exponential phase, the number of cells and the rate of population increase due to rapid cell division. The stationary phase is characterized by growth-limiting conditions, the growth rate and death rate are equal, thus, the number of individuals does not increase. Finally, there is a cell death phase that results from environmental stress.

Mathematical modeling is an essential and powerful tool to study and analyze microalgae growth under different physiological conditions. Mathematical models complement in vivo and in vitro experimental approaches and can also be used to design experiments. This tool has been utilized to provide insight into industries such as food and medicine ( $\mathrm{Li}$ et al., 2007). The use of mathematical models to describe and predict the behavior of microorganisms (growth, survival, and inactivation), occurs in two stages. First, an approximation using primary models to explain microorganism growth over time is used, these models can be deterministic or stochastic depending on the type of parameters and variables. Then, secondary models are brought up to describe the relationships between the parameters from the primary model and the environmental factors that affect the development of the microorganisms (Swinnen et al., 2004). Furthermore, growth kinetics combined with deterministic primary models have been used in empiric models with known functions such as Logistic, Gompertz, Richards, Schnute, Stannard, Ratkowsky, Weibull and Von Bertalanffy. Some of these models have modified versions using parameters with biological meaning (Halmi et al., 2014; Zwietering et al., 1990). Moreover, some primary models have a mechanistic conception and include parameters and functions with biological meaning like Baranyi-Roberts (1994, 1995) and Huang (2013) models.

In this sense, the aim of the present study was to monitor the growth of $N$. ellipsosporum under different light wavelengths and compare four deterministic primary models used to describe the species growth, three modified empirical: Logistic, Gompertz and Richards (Zwietering et al., 1990), and one mechanistic: Baranyi-Roberts (Baranyi \& 
Roberts, 1994, 1995) (Table 1), as a way to contribute to cyanobacteria biotechnological development. The modified growth models: Logistic, Gompertz, and Baranyi-Roberts are based on the maximum specific growth rate $\left(\mu_{\max }\right)$, i.e. the increase in the number of cells over time, the latency phase and the time. On the other hand, the modified Richards growth model introduces an additional parameter for adjustment $(v)$, which must always have a positive value considering that cellular growth is related to the binary fission of the parental cells in the culture medium and its minimum value has to be zero (Zwietering et al., 1990; Baranyi \& Roberts, 1994; Cayré et al., 2007; Merli \& Perazzi, 2017), since there cannot exist a negative number of cells (Cayré et al., 2007; Trejos et al., 2009; Infante et al., 2012; Castillo et al., 2017). At the same time, the mathematical model, as an abstraction of reality, must show an adjustment in its curves in order to closely represent the behavior of the experimental data, as it is the product of a complex interaction between environmental factors and the biology of the analyzed microorganism (Zwietering et al., 1990; Castillo et al., 2017; Merli \& Perazzi, 2017).

\section{Materials and methods}

\section{Strain information}

For growth experiments, Nostoc ellipsosporum was used (Göttingen Univ. B1453-79), provided by the Institute of Vegetal Biochemestry and Photosynthesis (IBVF) from the Center of Scientific Research Isla de Cartuja, Seville (Spain). N. ellipsosporum Rabenhorst ex Bornet \& Flahault belongs to the Prokaryotic domain, Eubacteria kingdom, Negibacteria subkingdom, Cyanobacteria phylum, Cyanophyceae class, Nostocophycidae subclass, Nostocales order and Nostocaceae family. They have a highly metabolic plasticity which allow them to endure high temperatures and acid environmental conditions, and inhabit different areas such as Great Britain, Czech Republic, Spain, Turkey, North-America, Argentina, Bangladesh, India, Iraq, Nepal and New Zealand (Nostoc ellipsosporum, 2018).

\section{Culture conditions}

$N$. ellipsosporum was cultivated in BD flasks with $30 \mathrm{ml}$ of BG-11 liquid medium for 9 days. The inoculum concentration was $1.1 \times 10^{4}$ cells $/ \mathrm{ml}$, and was isolated from a pre-culture at exponential phase and counted using a Neubauer chamber. The glass paper wrapping method was used to deduce the effect of light wavelengths on $N$. ellipsosporum biomass production, this technique is based on the principle that the color glass paper allows only a selective wavelength of light to pass through it; i.e., if red colored glass 
Table 1. Mathematical models used in the present study: Baranyi-Roberts, modified Gompertz, modified logistic and modified Richards.

Model

Modified logistic

Modified Gompertz

Modified Richards

Modified-Roberts

$$
\begin{aligned}
& \begin{aligned}
y(t)= & A+\mu_{\max } t+1 \mathrm{n}\left(e^{-\mu}\right. \\
& \frac{-1 \mathrm{n} 1+e^{\mu_{\max } t+1(e}}{}
\end{aligned} \\
& \mu_{\max }: \text { maximum specific growth rate, } \lambda \text { : lag time, } \\
& v \text { : adjustment parameter, } h_{0}=\mu_{\max } \lambda \text {. }
\end{aligned}
$$$$
\text { A: growth inferior asymptote }
$$

$y(t)=\ln (x(t))$, where $x(t)$ : cell density at moment $t$.

paper is used, then only red color light wavelength will pass through the paper (Rehman \& Dixit, 2019). Each glass paper was wrapped around the flask and $10 \mathrm{~cm}$ kept away from the light source (Kang et al., 2015; Ojit et al., 2015; Sanmartín et al., 2017; Rather \& Singh, 2018; Znad et al., 2018). Fluorescent lamps adjusted to 1200 lux using a lux meter were employed. A total of 12 experimental units were analyzed with the following treatments: white light $(400-800 \mathrm{~nm})$ as control treatment with no colored glass paper; red light (650-800 nm); yellow light $(550-580 \mathrm{~nm})$; and blue light $(460-480 \mathrm{~nm})$. Each experiment was performed in triplicate. The experimental units were kept under in controlled conditions such as $23^{\circ} \mathrm{C}$ and $12 \mathrm{~h}$ of photoperiod, according to the Biotechnology Laboratory at the Federal University of São Carlos (UFSCar) in Brazil (Camargo \& Lombardi, 2018). On days 1, 3, 5, 7, and 9, optical densities (OD) were measured using $1 \mathrm{ml}$ of $N$. ellipsosporum liquid culture and a spectrophotometer (Mettler Toledo) at $650 \mathrm{~nm}$. 


\section{Data processing}

All the results were analyzed by means of (one-way) ANOVA followed by Tukey HSD multiple comparisons. All statistical analyses were performed using SPSS (V. 21) software. $P<0.05$ was considered statistically significant.

All four chosen models, Baranyi-Roberts (Baranyi \& Roberts, 1994, 1995; Baranyi et al., 1995), modified Gompertz (Zwietering et al., 1990), modified Logistics (Gompertz, 1825; Zwietering et al., 1990) and Richards (Richards, 1959; Zwietering et al., 1990), consider biological meaningful parameters such as $\mu_{\max }$ (maximum specific growth rate) and $\lambda$ (lag time). Growth data was adjusted using a non-linear regression and the CurveExpert Basic 2.1.0 software, which employs the Marquardt algorithm. This algorithm minimizes the Residual Sums of Squares between predicted and experimental values, while providing correlation coefficient and standard error. The obtained data was adjusted to the four models, and the models were compared employing a F-test (Motulsky \& Ransnas, 1987).

\section{Results and Discussion}

Cyanobacteria began an adaptive diversification 3.5 billion years ago by optimizing oxygenic photosynthesis, managing to expand their ecological niches (Dhar et al., 2015). Such changes led to the evolution of a wide spectrum of photosynthetic pigments with specialized functions in order to compete with other autotrophic organisms (Morales et al., 2017; Benítez et al., 2018). Oxygenic photosynthetic organisms like cyanobacteria contain two types of reaction centers, P700 from photosystem I and P680 from photosystem II (Singh et al., 2015). Photosystems have chlorophyll as their main pigment and phycobilisomes (PBS) as light-harvesting antennae to optimize the absorption of light energy (Bland \& Angenent, 2016; Hagemann et al., 2016). PBS are supramolecular assemblies of water-soluble proteins named phycobiliproteins (PBP) and polypeptides (Ho et al., 2017). PBP are heterodimers of two structurally related but distinctly specialized polypeptides, $\alpha$ and $\beta$, made up of seven alpha-helices, each, which allow the complementary chromatic adaptation (Singh et al., 2015).

Cyanobacteria often feature an extensive range of colored pigments due to these highly fluorescent and covalently bound phycobiliproteins (Arteni et al., 2009). Some of these proteins are phycocyanin (CPC) with an absorption spectrum around 610-620 nm (blue), allophycocyanin (APC), having an absorption spectrum around 650-655 nm (blue grey), and phycoerythrin (CPE) around 540-570 nm (red) (Tiwari et al., 2015; Shukla et al., 2016; Garlapati et al., 2019). The absorption spectrum of phycobiliproteins is determined by an open-chain tetrapyrrole chromophore and the environment (Singh \& Singh, 2015). 
As mentioned before, phycobiliproteins have a very important role in regulating the distribution of the absorbed light energy between photosynthetic systems I and II, reason for which phycobiliproteins go under rapid changes when light is modified. This physiological mechanism allows cyanobacteria to adapt fast to environmental conditions. Therefore, light quality determines the intensity of all vital processes affecting yield and quality of the biomass obtained (Bland \& Angenent, 2016; Chen et al., 2016; Cepoi, 2019). In this scenario, the effect of different light wavelengths (i.e., red, yellow, blue and white) on the growth of Nostoc ellipsosporum was evaluated and the obtained results are presented next. Growth was monitored based on the optical density $\left(O D_{650}\right)$ over a 9-day incubation period.

\section{Laboratory results}

As shown in Fig. 1, N. ellipsosporum had significantly distinct levels of cell growth when cultivated under different light wavelengths.

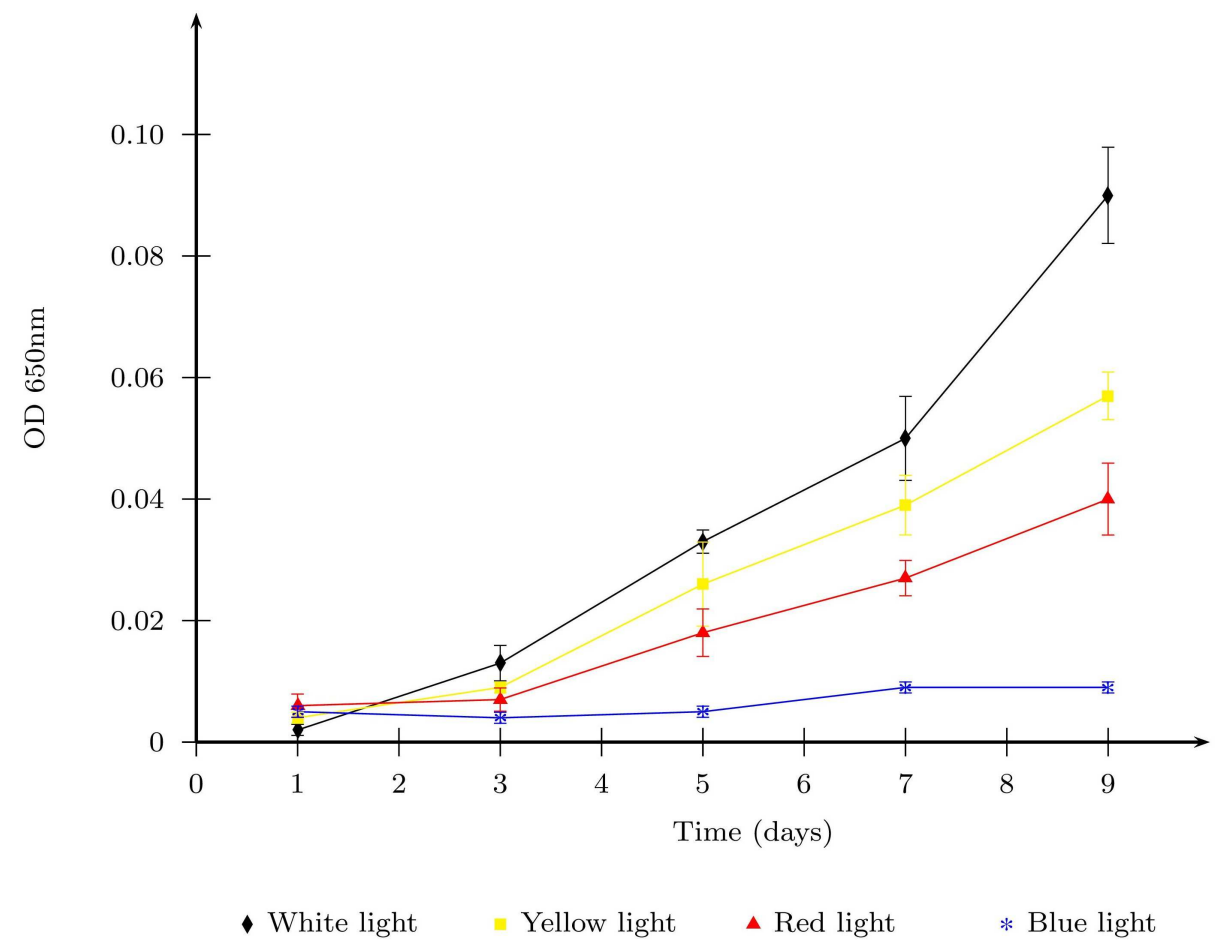

Figure 1. Growth curves from $N$. ellipsosporum under different light wavelength, treatments were as follow: white light $(400-800 \mathrm{~nm})$; red light $(650-800 \mathrm{~nm})$; yellow light $(550-580 \mathrm{~nm})$ and blue light $(460-480 \mathrm{~nm})$. OD: Optical density. 
The $\left(O D_{650}\right)$ of $N$. ellipsosporum was higher under white light conditions $(0.090 \pm 0.008)$, followed by yellow $(0.057 \pm 0.004)$, red $(0.040 \pm 0.006)$ and blue light $(0.009 \pm 0.001)$. These results may be due to the wider photo-spectrum distribution of white light $(400-800 \mathrm{~nm})$, which stimulates mostly all photosynthetic pigments from autotrophic microorganisms (Ho et al., 2014); as seen in microalgae Navicula incerta (Singh \& Singh, 2015) and cyanobacterium Nostoc flagelliforme (Han et al., 2014). Similarly, Kim et al (2013) reported that the cell growth rate of the microalgae Scenedesmus sp. was the highest under white light conditions, followed by red, blue, and green light, respectively. Zhao et al., also stated that the highest maximum specific growth rate and biomass productivity of microalgae Chlamydomonas sp. was under white light, then green, blue, and red (Zhao et al., 2019). Nevertheless, Das et al. reported that the biomass productivity of Spirulina platensis was the highest under red light condition, yet the maximum specific growth rate of Nannochloropsis sp. was achieved under blue light (Das et al., 2011). Since this is not the present case, it can be said that the effect of light wavelength on biomass production in photoautotrophic microalgae is species-dependent (Ho et al., 2014).

The growth of $N$. ellipsosporum showed a progressive increase from day 3 until day 9, under white, red and yellow lights (Fig. 1). The maximum $O D_{650}$ values were observed on day 9 of the incubation period. On the other hand, under blue light, the growth was stationary, almost non-existing, and slow from day 5 to day 9 .

$N$. ellipsosporum showed a similar trend in its growth curve under white light as previous growth curves reported by several authors in Nostoc flageliforme, Synechocystis sp. and Microcystis aeruginosa, exhibiting a lag phase during three days after inoculation and an exponential phase afterwards (Han et al., 2014; Bland \& Angenent, 2016; Crettaz Minaglia et al., 2017). Overall, comparison of the $O D_{650}$ using (one-way) ANOVA and Tukey HSD multiple comparisons showed that the $N$. ellipsosporum cells grew significantly better $(P=0.000 ; 98 \%$ correlation coefficient) under white light (control), and that blue light restricts cyanobacteria growth.

N. ellipsosporum photosynthetic system includes various pigments. The primary pigment is chlorophyll a, whose maximum absorption wavelength is $420 \mathrm{~nm}$, and is stimulated by white and blue lights (Singh \& Singh, 2015); since chlorophyll is the most abundant, the cyanobacterium grew better under the white light. Other pigments in the photosynthetic systems are phycocyanin with a maximum absorption at $620 \mathrm{~nm}$, it is stimulated by white, red and yellow lights; and phycoerythrin whose maximum absorption wavelength is $570 \mathrm{~nm}$ and is stimulated by white and yellow lights (Barsanti \& Gualtieri, 2006; Johnson et al., 2014). As described above, phycocyanin and 
phycoerythrin are pigments that efficiently harvest light energy and transfer it to photosynthetic reaction centers. They are produced to increase the range of light absorption, once the cyanobacterium needs alternative ways to get light and energy in order to grow. They are directly related and influenced by the composition of the light provided to the culture (Pagels et al., 2019). In the present study there was a slight adaptation of $N$. ellipsosporum when exposed to red and yellow light under the established conditions according to the $O D_{650}$ values, which suggest some increase in these proteins' contents and a consequent effect on the cellular growth and function. Likewise, Tiwari et al. observed that higher quantity of phycocyanin is produced under red light and phycoerythrin under green light in Nostoc muscorum, in order to guarantee the photosynthetic efficiency (Tiwari et al., 2015). However, acclimation to the different light quality is not horizontal and it varies according to the species. For example, it has been described that, under blue light, some Anabaena species increase the total phycobiliprotein productivity (Pagels et al., 2019). The same outcome has been observed in Nostoc sphaeroides (Ma et al., 2015). Nonetheless, no adaptation under blue light was observed in this study.

In photosynthetic organisms like $N$. ellipsosporum, carotenoids and xanthophylls serve as both light harvesting pigments and to protect cells from photooxidative damage. They absorb light from the green and blue regions $(380-580 \mathrm{~nm})$. Carotenoids production is related to the nutrient's availability in the genus Nostoc (Yang et al., 2019). When carotenoids are absent, the number of phycocyanin molecules connected to the phycobilisome nucleus is strongly reduced, thus, disturbing the organization of the thylakoid membrane and affecting the microalgae growth (Tóth et al., 2015). Under the experimental conditions of this study, $N$. ellipsosporum seems to be associated with low concentrations of carotenoids, similar to what has been described before (Loaiza et al., 2016; Rivera-González et al., 2017).

The inhibitory effect of blue light on the growth of $N$. ellipsosporum is comparable to the results from Ooms et al., where blue light also diminished Synechococcus sp. biomass production (Ooms et al., 2017); and to the results from Luimstra et al., which showed that cyanobacterium Synechocystis sp. displayed lower $\mathrm{O}_{2}$ and biomass production rates in blue light (Luimstra et al., 2018 , 2019). It was demonstrated that cyanobacteria have low photosynthetic efficiency in blue light because PBS does not absorb wavelengths under 450 $\mathrm{nm}$, and hence blue light mainly excites the photosystem I, while fewer photons excite the photosystem II reaction center (Solhaugh et al.,2014; Kirilovsky, 2015).

Also, although blue light absorption is strong, a great part of this energy is diverted to other metabolic paths (Itoh et al., 2014; Teo et al., 2014), 
resulting in cell division delays (Oldenhof et al., 2006). Furthermore, particular light wavelengths can enhance the production of specific metabolic products in closely related species. Han et al. showed in 2018 and 2019, that different light qualities influenced the gene expression of $N$. flagelliforme, and that cells treated under blue and red light showed more significant changes in carbohydrate metabolism, energy metabolism, amino acid metabolism, nucleotide metabolism, activities of key enzymes and signal transduction. Moreover, light quality was considered to be a key factor controlling the growth and exopolysaccharides biosynthesis (Han et al., 2018; Han et al., 2019).

\section{Mathematical modeling of data}

Turbidimetry allows the detection of small particles that diffract light in a culture medium according to its concentration, within the detection limits determined by the spectrophotometer used. Since it is a fast and low-cost methodology, it has been widely used to study bacterial growth through the measurement of optical density (OD) and is used as a tool for mathematical modeling of cellular growth (Dalgaard et al., 1994; Dalgaard \& Koutsoumanis, 2001; Santiesteban-López \& López-Malo, 2008; Belda-Galbis et al., 2011; Gupta et al., 2012; Tevatia et al., 2012; Mytilinaios et al., 2014; Pla et al., 2015; Ahmad et al., 2015; Ibrahim et al., 2018; Silva et al., 2018; You et al., 2018; Charlebois \& Balázsi, 2019).

Data from all four light wavelength treatments (white, yellow, red and blue), was adjusted to the selected models (Baranyi-Roberts, modified Gompertz, modified logistic and modified Richards). Estimation of the model with the better adjustment was based on correlation coefficient and the F-test (Table 2). An example of the adjustment is presented in Fig. 2 using data from $N$. ellipsosporum growth under yellow light. According to the correlation coefficient and the F-test, Baranyi-Roberts model showed the best adjustment to experimental data from all four treatments. This is particularly interesting considering it is a mechanical-based model; however, biological parameters were used from the initial approach. In this model (Baranyi \& Roberts, 1994, 1995), the starting point is that the variation of cell density $x(t)$ in time $t$ can be modeled from the initial value problem:

$$
\frac{d x}{d t}=\mu_{\max } \alpha(t) u(x) x, \quad x(0)=x_{0},
$$


Table 2. Correlation coefficient for adjustments of Baranyi-Roberts, modified Gompertz, modified logistic and modified Richards models to N. ellipsosporum growth under different light wavelengths: white light $(400-800 \mathrm{~nm})$; red light (650-800 nm); yellow light (550-580 nm) and blue light (460-480 nm).

\begin{tabular}{lcccc}
\hline \multicolumn{1}{c}{ Model } & $\begin{array}{c}\text { White light } \\
\text { treatment }\end{array}$ & $\begin{array}{c}\text { Yellow light } \\
\text { treatment }\end{array}$ & $\begin{array}{c}\text { Red light } \\
\text { treatment }\end{array}$ & $\begin{array}{c}\text { Blue light } \\
\text { treatment }\end{array}$ \\
\hline $\begin{array}{l}\text { Baranyi- } \\
\text { Roberts }\end{array}$ & 0.9974 & 0.9978 & 0.9903 & 0.9403 \\
$\begin{array}{l}\text { Modified } \\
\text { Gompertz }\end{array}$ & 0.9953 & 0.9964 & 0.9792 & 0.8579 \\
$\begin{array}{l}\text { Modified } \\
\text { Logistic }\end{array}$ & 0.9912 & 0.9977 & 0.9814 & 0.8662 \\
$\begin{array}{l}\text { Modified } \\
\text { Richards }\end{array}$ & 0.9953 & 0.9979 & 0.9842 & 0.8674 \\
\hline
\end{tabular}

where $\mu_{\max }$ is the maximum specific growth rate, $\alpha(t)$ is a function that describes the population adaptation to the new environment, $u(x)$ is a function that describes the inhibition growth at the end of the exponential phase and the beginning of the stationary phase.

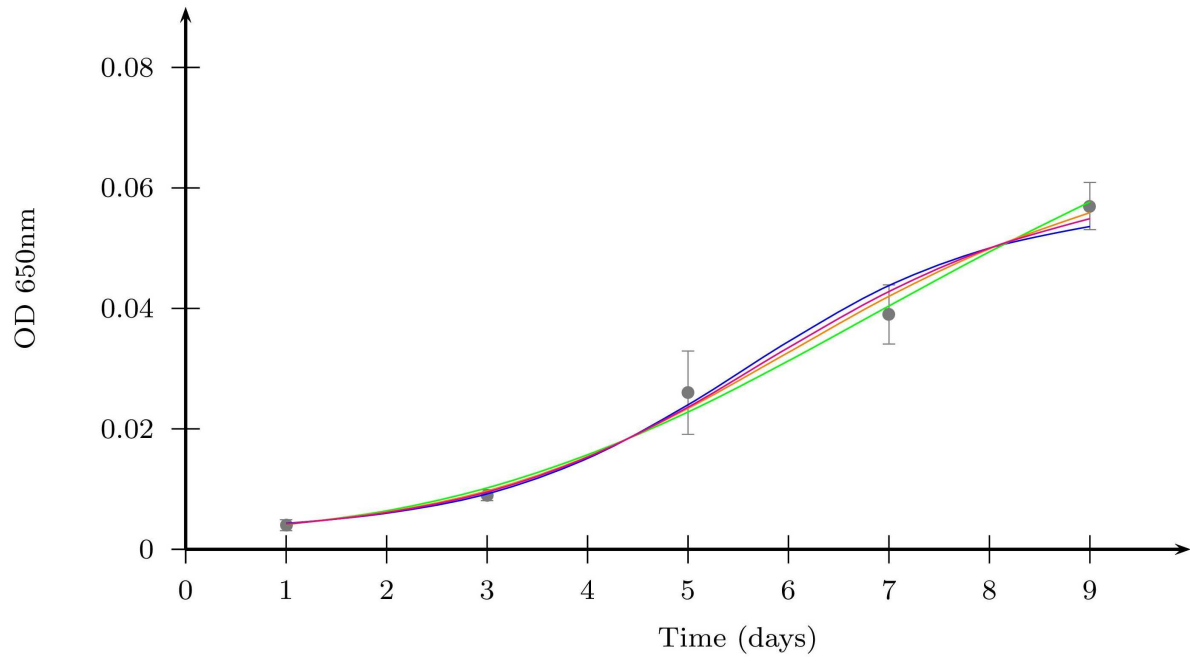

- Experimental data

— Baranyi-Roberts model

—_ Gompertz modified model

Logistic modified model

— Richards modified model

Figure 2. Growth curves from $N$. ellipsosporum using the mathematical models: Baranyi-Roberts, modified Gompertz, modified Logistic and modified Richards. All of them under yellow light treatment $(550-580 \mathrm{~nm})$. OD: optical density. 
If the inhibition function has a Logistic form and $x_{\max }$ represents the maximum density of the population, then:

$$
u(x)=1-\frac{x}{x_{\max }}
$$

Now, Baranyi \& Roberts model $(1994,1995)$ supposes that the adaptation function $\alpha(t)$ indicates the required medium to ensure microorganism growth in the new environment, using Michaelis-Menten kinetics, then:

$$
\alpha(t)=\frac{q(t)}{1+q(t)}
$$

where $q(t)$ represents the initial physiological state of the population. Under the assumption that $q(t)$ follows a first order kinetics, then:

$$
\frac{d q}{d t}=v q, \quad q(0)=q_{0}
$$

meaning that:

$$
\alpha(t)=\frac{q_{0}}{q_{0}+e^{-\mu_{\max } t}},
$$

where $q_{0}$ indicates the initial physiological state of the inoculum and it was taken from $v=\mu_{\max }$.

Changing the variable $y(t)=\ln (x(t)), y_{0}=\ln \left(x_{0}\right), y_{\max }=\ln \left(x_{\max }\right)$, the solution to the corresponding initial value problem is given by:

$$
\begin{aligned}
& y(t)=y_{0}+\mu_{\text {max }} A(t)-\ln \left(1+\frac{e^{\mu_{\max } A(t)}-1}{e^{y_{\max }-y_{0}}}\right) \\
& A(t)=t+\frac{1}{\mu_{\max }} \ln \left(\frac{e^{-\mu_{\max } t}+q_{0}}{1+q_{0}}\right) .
\end{aligned}
$$

If

$$
b_{0}=\ln \left(1+\frac{1}{q_{0}}\right) \text {, }
$$

then

$$
\begin{aligned}
y(t)= & y_{0}+\mu_{\max } t+\ln \left(e^{-\mu_{\max } t}+e^{-h_{0}}-e^{-\mu_{\max } t-h_{0}}\right) \\
& -\ln \left(1+\frac{e^{\mu_{\max } t+\ln \left(e^{-\mu_{\max } t}+e^{-h_{0}-e^{-\mu_{\max } t-h_{0}}}\right)}-1}{e^{y_{\max }-y_{0}}}\right)
\end{aligned}
$$


Using Baranyi-Roberts model $(1994,1995)$ as a base model, the effect of light wavelength on the growth of Nostoc ellipsosporum was adjusted (Fig. 3). The $\mu_{\max }$ values (1/day) were between 0.5161 to 1.1883 . Under the white light treatment (control) the lag phase was negative. Lag phase increased progressively in the yellow, red and blue light treatments (Table 3).

Over the last decades, the use of primary models to describe growth kinetics of microorganisms has increased, especially in microalgae research (Lacerda et al., 2011; Mohamed et al., 2014; Halmi et al., 2014). Among many mathematical models used, the Baranyi-Roberts model proved to be very useful in the present study, because its parameters have a direct biological interpretation, it can be applied to dynamic environmental conditions and can be adjusted to the experimental data.

A relationship between the natural logarithm of the OD and the natural logarithm of the cell density DC (cell $/ \mathrm{ml}$ ) was estimated in order to use the OD data in each treatment and calculate the respective cell concentration, considering that the optical density is directly proportional to the cell

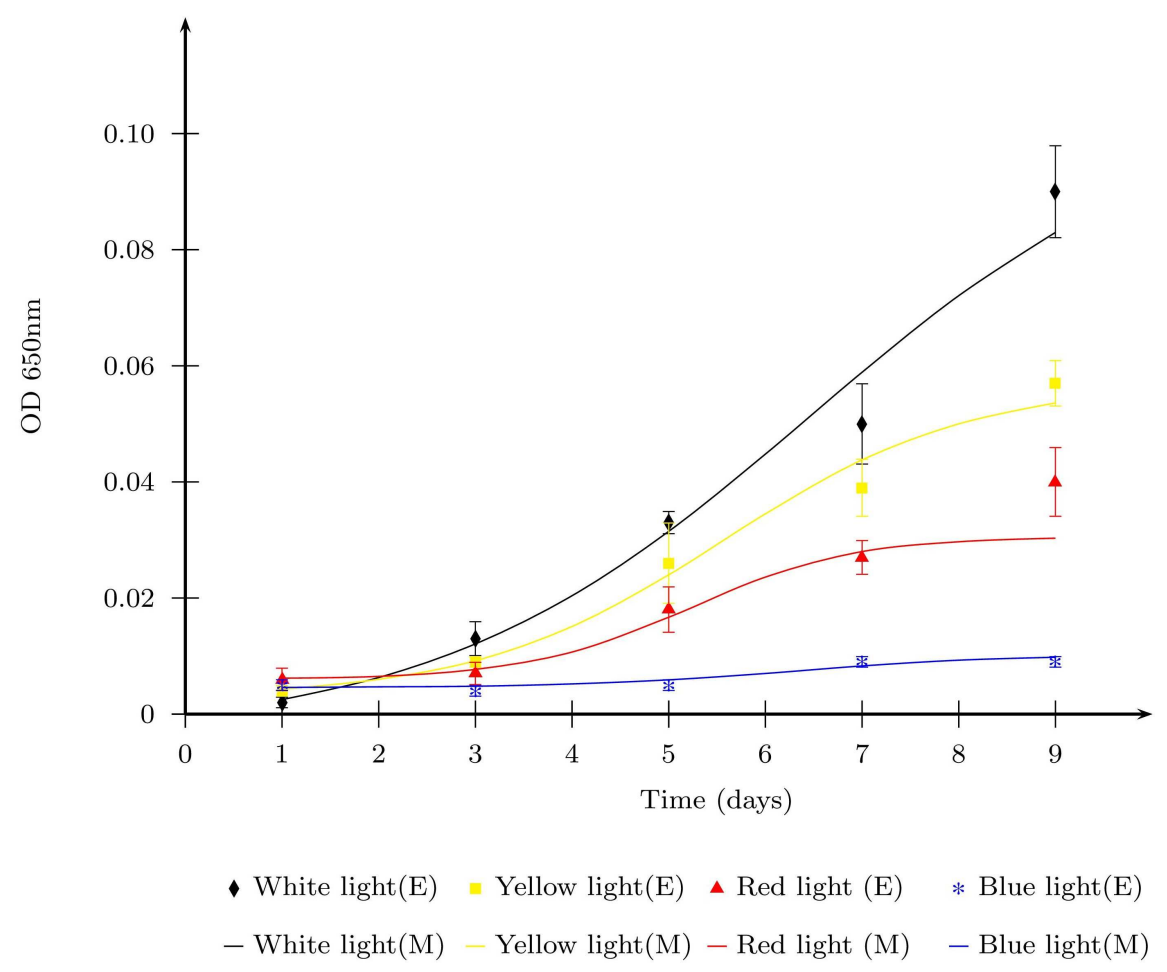

Figure 3. Growth curves from $N$. ellipsosporum under four light wavelength treatments. The curves were adjusted according to the Baranyi-Roberts mathematical model. OD: optical density, (E): Experimental, (M): Modelated. 
Table 3. Parameters adjusted according to the Baranyi-Roberts mathematical model for the growth of $N$. ellipsosporum under different light wavelengths.

\begin{tabular}{ccccc}
\hline Parameter & $\begin{array}{c}\text { White } \\
\text { light }\end{array}$ & $\begin{array}{c}\text { Yellow } \\
\text { light }\end{array}$ & $\begin{array}{c}\text { Red } \\
\text { light }\end{array}$ & $\begin{array}{c}\text { Blue } \\
\text { light }\end{array}$ \\
\hline$\mu_{\max }(1 /$ day) & 0.5161 & 0.7843 & 1.1883 & 0.9261 \\
$\lambda$ (day) & & 2.0277 & 3.8561 & 5.4740 \\
\hline
\end{tabular}

concentration and that it is a widely used parameter for monitoring cell growth (Infante et al., 2012; Vanegas \& Ramírez, 2016). Only when a strain reaches the phase of cellular death, due to a high cell concentration, nutrient depletion and accumulation of toxic metabolites; the cell concentration reduces and the cellular biomass is precipitated, thus altering the OD of the culture medium.

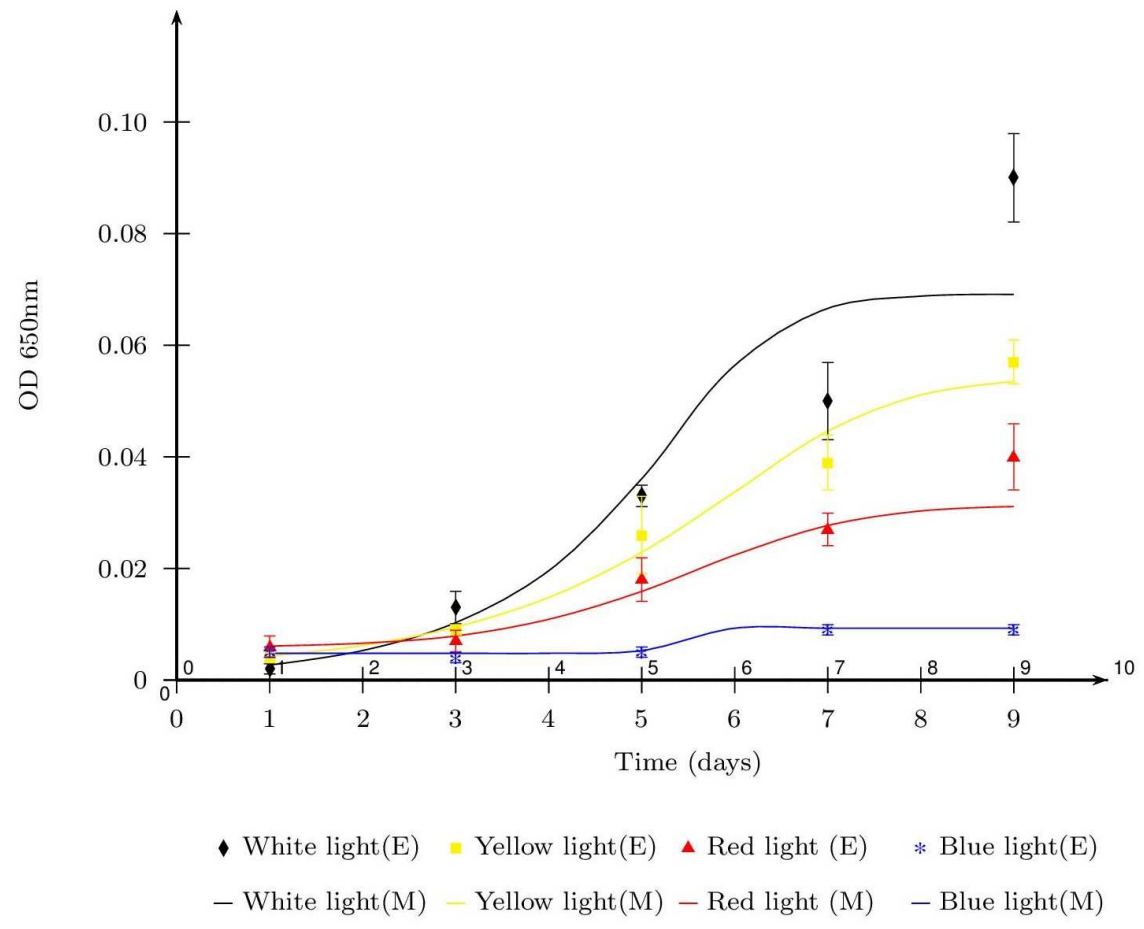

Figure 4. Growth curves from $N$. ellipsosporum under four light wavelength treatments. The curves were adjusted according to Baranyi-Roberts mathematical model (BR2): $y=303978 x+2 \times 10^{6}$; where $x=\ln (O D)$, $y=\ln (C D)$. OD: optical density. CD:cell density. 
Table 4. Parameters adjusted according to the Baranyi-Roberts mathematical model for the growth of $N$. ellipsosporum under different light wavelengths based on optical density data (BR1) and calibrated data (BR2).

\begin{tabular}{cccccccccc}
\hline Parameter & White light & \multicolumn{2}{c}{ Yellow light } & Red light & \multicolumn{2}{c}{ Blue light } \\
\hline Model & BR1 & BR2 & BR1 & BR2 & BR1 & BR2 & BR1 & BR2 \\
\hline$\mu_{\max }(1 /$ day) & 0.5161 & 11.1966 & 0.7843 & 1.3748 & 1.1883 & 1.3646 & 0.9261 & 1.9799 \\
\hline$\lambda$ (day) & & 5.0705 & 2.0277 & 0.7227 & 3.8561 & 2.7663 & 5.4740 & \\
\hline
\end{tabular}

This is why in batch cell culture systems, focused on cellular biomass production or its derivatives, cultivation is carried out until the phase of cellular death. It was found that when modeling the experimental data of OD using Baranyi-Roberts (BR1) a coefficient of determination value of $2.7 \times 10^{-4}$ is obtained, with a previous calibration curve (BR2) formed by the expression:

$$
y=303978 x+2 \times 10^{6}
$$

where: $x=\ln (O D), y=\ln (C D)$. A coefficient of determination of $1.36 \times 10^{-3}$ was obtained, showing a better fit of BR2 with the growth curve of N. ellipsosporum. When applying this method to the data from each treatment, the following coefficients of determination were found: $1.32 \times 10^{-4}$ (white light BR1) and $7.32 \times 10^{-4}$ (white light BR2); $3.83 \times 10^{-5}$ (yellow light BR1) and $5.39 \times 10^{-5}$ (yellow light BR2); $9.65 \times 10^{-5}$ (BR1 red light) and $8.43 \times 10^{-5}$ (BR2 red light); $2.79 \times 10^{-6}$ (blue light BR1) and $1.02 \times 10^{-6}$ (blue light BR2). BR1 had a better fit with the red light and blue light treatments, while BR2 better represented the white light and yellow light treatments data (Fig. 4). Table 4 shows the growth parameters of $N$. ellipsosporum under four treatments using different wavelengths of light and modeled with Baranyi-Roberts under conditions BR1 and BR2. This table shows that the white light treatment had the maximum growth rate $\mu_{\max }$. The resulting data demonstrated that it is possible to extend the Baranyi-Roberts model to other types of growth indicators, such as absorbance.

Lastly, similar approaches have modeled the growth of various microorganisms under different conditions also using OD measurement and the modified Baranyi-Roberts model. For example, Mytilinaios et al. (2014), 
examined the growth of Escherichia coli and Salmonella typhimurium under mild conditions of temperature, salt and $\mathrm{pH}$; and concluded that a rearranged Baranyi-Roberts model could be used with time to detection data obtained from optical density measurements, producing highly accurate specific growth rates and lag phase durations (Mytilinaios et al., 2014). In 2005, Perni et al., found that the values of $\mu_{\max }$ obtained by using the Gompertz, logistic and Baranyi-Roberts models, with absorbance and viable counts measurements of cell concentration, fitted the experimental data from the growth of Listeria monocytogenes and Listeria innocua well (Perni et al., 2005). Moreover, growth curves of Bacillus cereus, L. monocytogenes and $E$. coli with different initial concentrations were analyzed measuring the microbial growth by optical density, and using mathematical models that provided a good fitting for all growth curves, especially the Baranyi model (Pla et al., 2015). Furthermore, once again, the measurement of absorbance was used to monitor cell concentration in three species of lactic acid bacteria, to model their growth. Primary models Baranyi-Roberts and Gompertz were used, achieving a slightly better fit to the experimental data when using the first one (Silva et al., 2018).

\section{Conclusions}

In this study, it was investigated the effects of three different light wavelengths (yellow, red and blue) and a control light wavelength (white) on Nostoc ellipsosporum growth. The experimental results indicated that white light $10 \mathrm{~cm}$ away and at 1200 lux was significantly more efficient for $N$. ellipsosporum growth compared to the other light wavelengths. The highest optical density $\left(O D_{650}\right)$ value was read as 0.099 on day 9 of the incubation period. Growth under yellow and red light was registered as well. However, blue light inhibited N. ellipsosporum growth. Nevertheless, the present study only provides insight into the effect of light quality on the growth and biomass accumulation of $N$. ellipsosporum, if the production of specific bioproducts is required, further investigation must occur.

From the analyzed models, the one that proved to have a better fit with the experimental data from $N$. ellipsosporum in all four treatments was the Baranyi-Roberts model. Modeling provides a valuable quantitative approach to understanding different aspects of microalgae physiology and growth, this is a fundamental step for industrial exploitation.

\section{Acknowledgements}

The authors thank the General Research Center from Universidad de los Llanos for supporting the research project: "Modelamiento matemático 
del crecimiento de un alga perifítica con potencial biotecnológico"code C01-F02-020-201; to Colciencias for the funding provided to the experimental phase with the grant 497 for doctoral studies abroad; and finally, to the Biotechnology Laboratory at the Federal University of São Carlos (UFSCar) in Brazil for the logistic support, especially to Prof. Dr. Ana Teresa Lombardi, the biologist Carlos Casali and Dr. Renata Haneda.

\section{Conflict of interest}

The authors declare no conflict of interest.

\section{References}

Abed RMM, Dobretsov S, \& Sudesh K. Applications of cyanobacteria in biotechnology. Journal of Applied Microbiology, 106(1), 1-12, 2009.

Ahmad SA, Shukor MS, Masdor NA, Shamaan NA, Roslan MAH, Shukor MY. The growth of Paracoccus sp. SKG on acetonitrile is best modelled using the Buchanan three phase model. Journal of Environmental Bioremediation and Toxicology, 3 (1): 1-5, 2015.

Retrieved from:

https://journal.hibiscuspublisher.com/index.php/JEBAT/ article/view/253

Algal culturing techniques. (R.A. Andersen Ed.). Burlington: Phycological society of America, 2005.

Andersen RA. Algal culturing techniques, Phycological society of America, Burlington, USA, 2005.

Arteni AA, Ajlani G, \& Boekema EJ. Structural organization of phycobilisomes from Synechocystis sp. strain PCC6803 and their interaction with the membrane. Biochimica et Biophysica Acta, 1787 (4), 272-279, 2009.

doi: 10.1016/j.bbabio.2009.01.009

Atta M, Idris A, Bukhari A, \& Wahidin S. Intensity of blue LED light: A potential stimulus for biomass and lipid content in fresh water microalgae Chlorella vulgaris. Bioresource Technology, 148, 373378, 2013.

doi: 10.1016/j.biortech.2013.08.162

Baranyi J, \& Roberts TA. A dynamic approach to predicting bacterial growth in food. International Journal of Food Microbiology, 23(3-4), 277-294, 1994.

doi: 10.1016/0168-1605(94)90157-0 
Baranyi J, \& Roberts TA. Mathematics of predictive food microbiology. International Journal of Food Microbiology, 26(2), 199218, 1995.

doi: 10.1016/0168-1605(94)00121-L

Baranyi J, Robinson TP, Kaloti A, \& Mackey BM. Predicting growth of Brochothrix thermosphacta at changing temperature. International Journal of Food Microbiology, 27(1), 61-75, 1995.

doi: 10.1016/0168-1605(94)00154-X

Barsanti L, \& Gualtieri P. Algae: anatomy, biochemistry and biotechnology. Boca Raton: CRC Press Taylor \& Francis group, 2006.

Belda-Galbis CM, Martínez A, Rodrigo D. Antimicrobial effect of carvacrol on Escherichia coli K12 growth at different temperatures, 2011. doi: 10.1142/9789814354868_0015

Benítez REH, Vidal DRA, \& Guerrero JV. Efecto de la Inoculación de Cianobacterias en Cultivos de Interés Comercial en Zonas Semiáridas de La Guajira-Colombia. Revista Colombiana de Investigaciones Agroindustriales, 5(1), 20-31, 2018.

doi: $10.23850 / 24220582.889$

Bland E, \& Angenent LTJ. Pigment-targeted light wavelength and intensity promotes effcient photoautotrophic growth of Cyanobacteria. Bioresource technology, 216, 579-586, 2016.

doi: 10.1016/j.biortech.2016.05.116

Camargo EC, \& Lombardi AT. Effect of cement industry flue gas simulation on the physiology and photosynthetic performance of Chlorella sorokiniana. Journal of Ap-plied Phycology, 30 (2), 861-871, 2018.

doi: $10.1007 /$ s10811-017-1291-3

Castillo CMN, Rivera FCR, Díaz LE, Díaz AGL. Evaluación de las condiciones de crecimiento celular para la producción de astaxantina a patir de la microalga Haematococcus pluvialis, Nova, 15 (28): 19-31, 2017.

Retrieved from

http://hemeroteca.unad.edu.co/index.php/nova/article/ view/2073/2273 
Cayré ME, Vignolo GM, Garro OA. Selección de un modelo primario para describir la curva de crecimiento de bacterias lácticas y Brochothrix thermosphacta sobre emulsiones cárnicas cocidas, Información Tecnológica, 18(3): 23-29, 2007.

doi: 10.4067/S0718-07642007000300004

Celekli A, Yavuzatmaca M, \& Bozkurt H. Modeling of biomass production by Spirulina platensis as function of phosphate concentrations and $\mathrm{pH}$ regimes. Bioresource Technology, 100, 3625-3629, 2009.

doi: 10.1016/j.biortech.2009.02.055

Cepoi L. Chapter 11: Environmental and Technological Stresses and Their Management in Cyanobacteria. In: Cyanobacteria From Basic Science to Applications. Mishra AK, Tiwari DN, \& Rai AN (Eds.). Elsevier, 217-244, 2019.

Retrieved from

https: / / www.elsevier.com/books / cyanobacteria / mishra/978-0-12-814667-5

Charlebois DA, Balázsi G. Modeling cell population dynamics. In Silico Biology, 13 (1-2): 21-39, 2019.

doi: $10.3233 /$ ISB-180470

Chen Q, Montesarchio D, \& Hellingwerf KJ. 'Direct conversion': artificial photosynthesis with cyanobacteria. In Advances in Botanical Research, 79, 43-62, 2016.

doi: 10.1016/bs.abr.2016.03.001

Chiu SY, Kao CY, Chen CH, Kuan TC, Ong SC, \& Lin CS. Reduction of $\mathrm{CO} 2$ by a high-density culture of Chlorella sp. in a semicontinuous photobioreactor. Bioresource Technology, 99, 3389-3396, 2008.

doi: 10.1016/j.biortech.2007.08.013

Cibichakravarthy B, Venkatachalam S, \& Prabagaran SR. Chapter 9: Unleashing Extremophilic Metabolites and Its Industrial Perspectives. In: Gupta BK, \& Pande A (Eds). New and Future Developments in Microbial Biotechnology and Bioengineering. 119-130, 2019.

doi: 10.1016/B978-0-444-63504-4.00009-8 
Crettaz Minaglia MC, Rosso L, Aranda O, Sedan D, Juárez I, Ventosi E, Gian-nuzzi LJI. Modelado matemático del crecimiento de Microcystis aeruginosa en condiciones de laboratorio bajo diferentes temperaturas. Ingeniería Sanitaria y Ambiental, 61-67, 2017.

http: / / hdl.handle.net/10915/60750

Crnkovic CM, May DS, \& Orjala J. The impact of culture conditions on growth and metabolomic profiles of freshwater cyanobacteria. Journal of Applied Phycology, 1-10, 2017.

doi: 10.1007/s10811-017-1275-3

Cui L, Xu H, Zhu Z, \& Gao X. The effects of the exopolysaccharide and growth rate on the morphogenesis of the terrestrial filamentous cyanobacterium Nostoc flagelliforme. Biology open, 6(9), 1329-1335, 2017.

doi: $10.1242 /$ bio.026955

Dalgaard P, Koutsoumanis K. Comparison of maximum specific growth rates and lag times estimated from absorbance and viable count data by different mathematical models. Journal of Microbiological Methods, 43: 183-196, 2001.

doi: 10.1016/s0167-7012(00)00219-0

Dalgaard P, Ross T, Kamperman L, Neumeyer K, McMeekin TA. Estimation of bacterial growth rates from turbidimetric and viable count data. International Journal of Food Microbiology, 23: 391-404, 1994.

doi: 10.1016/0168-1605(94)90165-1

Das P, Lei W, Aziz SS, \& Obbard JP. Enhanced algae growth in both phototrophic and mixotrophic culture under blue light. Bioresource Technology, 102, 3883-3887, 2011.

doi: 10.1016/j.biortech.2010.11.102

Da Silva Ferreira V, \& Sant'Anna C. Impact of culture conditions on the chlorophyll content of microalgae for biotechnological applications. World J Microbiol Biotechnol, 33(1), 20, 2017.

doi: 10.1007/s11274-016-2181-6

De Oliveira CA, Castro-Oliveira W, \& Rocha SM. Effect of light intensity on the production of pigments in Nostoc spp. European Journal of Biology and Medical Science Research, 2(1), 23-36, 2014. 
Delattre C, Pierre G, Laroche C, \& Michaud P. Production, extraction and characterization of microalgal and cyanobacterial exopolysaccharides. Biotechnol Adv, 34(7), 1159-1179, 2016.

doi: 10.1016/j.biotechadv.2016.08.001

Dhar DW, Prasanna R, Pabbi S, \& Vishwakarma R. Significance of cyanobacteria as inoculants in agriculture. In Algal Biorefinery: An Integrated Approach (pp. 339-374): Springer. 2015.

doi: 10.1007/978-3-319-22813-6_16

Fuentes J, Garbayo I, Cuaresma M, Montero Z, González-del-Valle M, \& Vílchez C. Impact of microalgae-bacteria interactions on the production of algal biomass and associated compounds. Marine Drugs, 14 (5), 100, 2016.

doi: $10.3390 / \operatorname{md} 14050100$

Garlapati D, Chandrasekaran M, Devanesan A, Mathimani T, \& Pugazhendhi A. Role of cyanobacteria in agricultural and industrial sectors: an outlook on economically important byproducts. Applied Microbiology and Biotechnology, 103 (12), 4709-4721, 2019.

doi: $10.1007 /$ s00253-019-09811-1

Gaytán-Luna DE, Ochoa-Alfaro AE, Rocha-Uribe A, PérezMartínez AS, Alpuche-Solís Á, \& Soria-Guerra RE. Effect of green and red light in lipid accumulation and transcriptional profile of genes implicated in lipid biosynthesis in Chlamydomonas reinhardtii. Biotechnol Prog, 32(6), 1404-1411, 2016.

doi: $10.1002 /$ btpr.2368

Gompertz B. On the nature of the function expressive of the law of human mortality, and on a new mode of determining the value of life contingencies. Philosophical transactions of the Royal Society of London, 115, 513-583, 1825.

doi: $10.1098 /$ rstl.1825.0026

Griffiths MJ, Garcin C, Van Hille RP, \& Harrison ST. Interference by pigment in the estimation of microalgal biomass concentration by optical density. Journal of Microbiological Methods, 85(2), 119-123, 2011.

doi: 10.1016/j.mimet.2011.02.005 
Guo F, Zhao JAL, \& Yang X. Life cycle assessment of microalgaebased aviation fuel: Influence of lipid content with specific productivity and nitrogen nutrient effects. Bioresource Technology, 221, 350-357, 2016.

doi: 10.1016/j.biortech.2016.09.044

Gupta S, Cox S, Rajauria G, Jaiswal AK, Abu-Ghannam N. Growth inhibition of common food spoilage and pathogenic microorganisms in the presence of brown seaweed extracts, Food and Bioprocess Technology, 5: 1907-1916, 2012.

doi: 10.1007/s11947-010-0502-6

Hagemann M, Kern R, Maurino VG, Hanson DT, Weber AP, Sage RF, \& Bauwe H. Evolution of photorespiration from cyanobacteria to land plants, considering protein phylogenies and acquisition of carbon concentrating mechanisms. Journal of experi-mental botany, 67(10), 2963-2976, 2016.

doi: $10.1093 /$ jxb/erw063

Hai T, Ahlers H, Gorenflo V, \& Steinbüchel A. Axenic cultivation of anoxygenic phototrophic bacteria, cyanobacteria, and microalgae in a new closed tubular glass photobioreactor. Applied Microbiology and Biotechnology, 53, 383-389, 2000.

doi: $10.1007 / \mathrm{s} 002530051630$

Halmi MIE, Shukor MS, Johari WLW, \& Shukor MY. Evaluation of several mathematical models for fitting the growth of the algae Dunaliella tertiolecta. Asian Journal of Plant Biology, 2(1), 1-6. 2014.

Retrieved from

http://journal.hibiscuspublisher.com/index.php/AJPB/ article/view/81

Han PP, Guo RJ, Shen SG, Yan RR, Wu YK, Yao SY, Wang HY, \& Jia SR. Proteomic profiling of Nostoc flagelliforme reveals the common mechanism in promoting polysaccharide production by different light qualities. Biochemical Engineering Journal, 132, 68-78, 2018.

doi: 10.1016/j.bej.2017.12.006

Han PP, Shen SG, Wang HY, Sun Y, Dai YJ, \& Jia SR. Comparative metabolomic analysis of the effects of light quality on polysaccharide production of cyanobacterium Nostoc flagelliforme. Algal Research, 9, 143-150, 2015.

doi: 10.1016/j.algal.2015.02.019 
Han PP, Shen SG, Guo RJ, Zhao DX, Lin YJ, Jia S, Yan RR, \& Wu YK. ROS is a factor regulating the increased polysaccharide production by light quality in the edible cyanobacterium Nostoc flagelliforme. Journal of Agricultural and Food Chemistry, 67 (8), 2235-2244, 2019.

doi: $10.1021 /$ acs.jafc. 8 b06176

Han PP, Shen SG, Wang HY, Yao SY, Tan ZL, Zhong C, \& Jia SR. Applying the strategy of light environment control to improve the biomass and polysaccharide production of Nostoc flagelliforme. Journal of Applied Phycology, 29 (496), 55-65, 2017 a.

doi: 10.1007/s10811-016-0963-8

Han PP, Sun Y, Jia SR, Zhong C, \& Tan ZLJC. Effects of light wavelengths on extracellular and capsular polysaccharide production by Nostoc flagelliforme. Carbohydrate polymers, 105, 145-151, 2014.

doi: 10.1016/j.carbpol.2014.01.061

Han PP, Yao SY, Guo RJ, Yan RR, Wu YK, Shen SG, \& Jia SR. Influence of culture conditions on extracellular polysaccharide production and the activities of enzymes involved in the polysaccharide synthesis of Nostoc flagelliforme. RSC Advances, 7, 45075-45084, 2017b.

doi: 10.1039/C7RA07982F

Ho SH, Chan MC, Liu CC, Chen CY, Lee WL, Lee DJ, \& Chang JS. Enhancing lutein productivity of an indigenous microalga Scenedesmus obliquus FSP-3 using light-related strategies. Bioresource Technology, 152, 275-282, 2014.

doi: 10.1016/j.biortech.2013.11.031

Ho MY, SoulierNT, Canniffe DP, Shen G, \& BryantDAJ. Light regulation of pigment and photosystem biosynthesis in cyanobacteria. 37, 24-33, 2017.

doi: $10.1016 / j \cdot p b i .2017 .03 .006$

Huang L. Optimization of a new mathematical model for bacterial growth. Food Control, 32(1), 283-288, 2013.

doi: 10.1016/j.foodcont.2012.11.019 
Ibrahim S, Mansur A, Ahmad SA. Mathematical modelling of the growth of Caulobacter crescentus on caffeine. Journal of Environmental Microbiology and Toxicology, 6 (2): 13-17, 2018.

Retrieved from

https://journal.hibiscuspublisher.com/index.php/JEMAT/ article/view/438

Infante C, Angulo E, Zárate A, Florez JZ, Barrios F, \& Zapata C. Propagación de la microalga Chlorella sp. en cultivo por lote: cinética del crecimiento celular. Avances en Ciencias e Ingeniería, 3(2), 2012.

Retrieved from

http://www.redalyc.org/pdf/3236/323627686016.pdf

Itoh KI, Nakamura K, Aoyama T, Kakimoto T, Murakami M, \& Takido T. The influence of wavelength of light on cyanobacterial asymmetric reduction of ketone. Tetrahedron Letters, 55(2), 435-437, 2014.

doi: 10.1016/j.tetlet.2013.11.049

Johnson EM, Kumar K, \& Das D. Physicochemical parameters optimization, and purification of phycobiliproteins from the isolated Nostoc sp. Bioresource technology, 166, 541-547, 2014.

doi: 10.1016/j.biortech.2014.05.097

Kang Z, Kim BH, Ramanan R, Choi JE, Yang JW, Oh HM, \& Kim HS. A cost analysis of microalgal biomass and biodiesel production in open raceways treating municipal wastewater and under optimum light wavelength. Journal of Microbiology and Biotechnology, 25(1), 109-118. 2015.

doi: 10.4014/jmb.1409.09019

Khajepour F, Hosseini SA, Nasrabadi RG, \& Markou G. Effect of light intensity and photoperiod on growth and biochemical composition of a local isolate of Nostoc calcicola. Applied biochemistry and biotechnology, 176(8), 2279-2289, 2015.

doi: $10.1007 /$ s12010-015-1717-9

Khanna P, Kaur A, \& Goyal D. Algae-based metallic nanoparticles: Synthesis, characterization and applications. Journal of Microbiological Methods, 163, 105656, 2019.

doi: 10.1016/j.mimet.2019.105656 
Kim TH, Lee Y, Han SH, \& Hwang SJ. The effects of wavelength and wavelength mixing ratios on microalgae growth and nitrogen, phosphorus removal using Scenedesmus sp. for wastewater treatment. Bioresource Technology, 130, 75-80, 2013.

doi: 10.1016/j.biortech.2012.11.134

Kim YS, \& Lee SH. Quantitative analysis of Spirulina platensis growth with $\mathrm{CO}_{2}$ mixed aeration. Environmental Engineering Research, 23(2), 216-222, 2018.

doi: $10.4491 /$ eer. 2017.193

Kirilovsky D. Modulating energy arriving at photochemical reaction centers: orange carotenoid protein-related photoprotection and state transitions. Photosynthesis Research, 126: 3-17, 2015.

doi: $10.1007 /$ s11120-014-0031-7

Kokabi M, Yousefzadi M, Soltani M, \& Arman M. Effects of different UV radiation on photoprotective pigments and antioxidant activity of the hot-spring cyanobacterium Leptolyngbya cf. fragilis. Phycological Research, 67 (3), 215-220, 2019.

doi: $10.1111 /$ pre. 12374

Lacerda LMCF, Queiroz MI, Furlan LT, Lauro MJ, Modenesi K, Jacob-Lopes E, \& Franco TT. Improving refinery wastewater for microalgal biomass production and $\mathrm{CO}_{2}$ biofixation: Predictive modeling and simulation. Journal of petroleum science and en-gineering, 78(3-4), 679-686, 2011.

doi: $10.1016 /$ j.petrol.2011.07.003

Li H, Xie G, \& Edmondson A. Evolution and limitations of primary mathematical models in predictive microbiology. British food journal, 109(8), 608-626, 2007.

doi: $10.1108 / 00070700710772408$

Liu X, Sheng J, \& Curtiss R. Fatty acid production in genetically modified cyanobacteria. Proceedings of the National Academy of Sciences, 2011.

doi: $10.1073 /$ pnas. 1103014108

Loaiza NR, Vera P, Aiello-Mazzarri C, \& Morales EJA. Comparación del crecimiento y composición bioquímica de cuatro cepas de Nostoc y Anabaena (Cyanobacteria, Nostocales) en relación con el nitrato de sodio. Acta Biológica Colombiana, 21(2), 347-354, 2016.

doi: $10.15446 /$ abc.v21n2.48883 
Lotfi H, Hejazi MA, Heshmati MK, Mohammadi SA, \& Zarghami N. Optimizing expression of antiviral cyanovirin-N homology gene using response surface methodology and protein structure prediction. Cell Mol Biol (Noisy-le-grand), 63(9), 96-105, 2017.

doi: $10.14715 / \mathrm{cmb} / 2017.63 .9 .17$

Luimstra VM, Schuurmans JM, Verschoor AM et al. Blue light reduces photosynthetic effciency of cyanobacteria through an imbalance between photosystems I and II. Photosynthesis Research, 138, 177-189, 2018.

doi: 10.1007/s11120-018-0561-5

Luimstra VM, Schuurmans JM, de Carvalho CFM, Matthijs HCP, Hellingwerf KJ, Huisman J. Exploring the low photosynthetic effciency of cyanobacteria in blue light using a mutant lacking phycobilisomes. Photosynthesis Research, 1-11, 2019.

doi: 10.1007/s11120-019-00630-z

Ma R, Lu F, Bi Y, \& Hu Z. Effects of light intensity and quality on phycobiliprotein accumulation in the cyanobacterium Nostoc sphaeroides Kützing. Biotechnology Letters, 37, 1663-1669, 2015.

doi: 10.1007/s10529-015-1831-3

Makhalanyane TP, Valverde A, Velázquez D, Gunnigle E, Van Goethem MW, Quesada A, \& Cowan DAJ. Ecology and biogeochemistry of cyanobacteria in soils, permafrost, aquatic and cryptic polar habitats. Biodiversity and Conservation, 24(4), 819-840, 2015.

doi: 10.1007/s10531-015-0902-z

Margarites AC, Volpato N, Araújo E, Cardoso LG, Bertolin TE, Colla LM, \& Costa JA. Spirulina platensis is more effcient than Chlorella homosphaera in carbohydrate productivity. Environ Technol, 1-8, 2016.

doi: 10.1080/09593330.2016.1254685

McBride RC, Smith VH, Carney LT, \& Lane TW. Crop protection in open ponds. In: Slocombe SP, \& Benemann JR (Eds.). Microalgal Production for Biomass and High-Value Products, 1st ed., CRC Press, 165-182, 2016.

Merli GO, Perazzi JR. Modelos de crecimiento en microbiología predictiva (Ecología microbiana cuantitativa). Estimación de modelos y simulación mediante dinámica de sistemas, XXVII Simposio Internacional de Estadistica 5th International Workshop on Applied Statistics, Medellín, Colombia, 2017. 
Mohamed MS, Tan JS, Kadkhodaei S, Mohamad R, Mokhtar MN, \& Ariff AB. Kinetics and modeling of microalga Tetraselmis sp. FTC 209 growth with respect to its adaptation toward different trophic conditions. Biochemical engineering journal, 88, 30-41, 2014.

doi: 10.1016/j.bej.2014.04.002

Morales E, Luna V, Navarro L, Santana V, Gordillo A, \& Arévalo AJRE. Diversidad de microalgas y cianobacterias en muestras provenientes de diferentes provincias del Ecuador, destinadas a una colección de cultivos. Revista Ecuatoriana de Medicina y Ciencias Biológicas, 34(1-2), 129-149, 2017.

doi: $10.26807 /$ remcb.v34i1-2.240

Motulsky HJ, \& Ransnas LA. Fitting curves to data using nonlinear regression: a practical and nonmathematical review. The FASEB journal, 1(5), 365-374, 1987.

doi: 10.1096/fasebj.1.5.3315805

Mytilinaios I, Bernigaud I, Belot V, \& Lambert RJW. Microbial growth parameters obtained from the analysis of time to detection data using a novel rearrangement of the Baranyi-Roberts model. Journal of applied microbiology, 118(1), 161-174, 2014.

doi: $10.1111 /$ jam.12695

Nostoc ellipsosporum, (2018).

Retrieved from

http://www.algaebase.org/search/species/detail/?species $\mathrm{id}=32575$

Novoveska L, Franks DT, Wulfers TA, \& Henley WJ. Stabilizing continuous mixed cultures of microalgae. Algal Research, 13(C), 126-133. 2016.

doi: 10.1016/j.algal.2015.11.021

Nozzi NE, Oliver JW, \& Atsumi S. Cyanobacteria as a platform for biofuel production. Frontiers in Bioengineering and Biotechnology, $1(7), 2013$

doi: 10.3389/fbioe.2013.00007

Oldenhof H, Zachleder V, \& Van Den Ende H. Blue-and redlight regulation of the cell cycle in Chlamydomonas reinhardtii (Chlorophyta). European Journal of Phycology, 41(3), 313-320, 2006.

doi: 10.1080/09670260600699920 
Ojit S, Indrama T, Gunapati O, Avijeet SO, Subhalaxmi AS, Silvia $\mathrm{CH}$, Indira DW, Romi KH, Minerva SH, \& Thadoi DA. The response of phycobiliproteins to light qualities in Anabaena circinalis. Journal of Applied Biology and Biotechnology, 3, 1-6, 2015. doi: 10.7324/JABB.2015.3301

Ooms MD, Graham PJ, Nguyen B, Sargent EH, \& Sinton D. Light dilution via wave-length management for effcient high-density photobioreactors. Biotechnology and bioengineering, 114(6), 1160-1169, 2017.

doi: 10.1002/bit.26261

Pagels F, Guedes AC, Amaro HM, Kijjoa A, \& Vasconcelos V. Phycobiliproteins from cyanobacteria: Chemistry and biotechnological applications. Biotechnology Advances, 37 (3), 422-443, 2019.

doi: 10.1016/j.biotechadv.2019.02.010

Pang K, Tang Q, Chen L, Wan B, Niu C, Yuan X, \& Xiao S. NitrogenFixing heterocystous cyanobacteria in the Tonian period. Current Biology, 28(4), 616-622, 2018.

doi: 10.1016/j.cub.2018.01.008

Park H, \& Lee CG. Theoretical Calculations on the Feasibility of Microalgal Biofuels: Utilization of Marine Resources Could Help Realizing the Potential of Microalgae. Biotechnol J, 11(11), 1461-1470, 2016.

doi: 10.1002/biot.201600041

Pereyra DSV, \& Ferrari SG. Extracellular Polymeric Substance (EPS) Production by Nostoc minutum under Different Laboratory Conditions. Advances in Microbiology, 6(05), 374, 2016.

doi: 10.4236/aim.2016.65036

Perni S, Andrew PW, Shama G. Estimating the maximum growth rate from microbial growth curves: definition is everything. Food microbiology, 22 (6): 491-495, 2005.

doi: $10.1016 /$ j.fm.2004.11.014

Pla ML, Oltra S, Esteban MD, Andreu S, Palop A. Comparison of primary models to predict microbial growth by the plate count and absorbance methods. BioMed Research International, 365025, 2015.

doi: $10.1155 / 2015 / 365025$ 
Rather AH, \& Singh S. Preliminary evaluation of impact of monochromatic light on the biosynthesis of astaxanthin in green alga Haematococcus pluvialis. World News of Natural Sciences, 19, 45-50, 2018.

YADDA identifier:

bwmeta1.element.psjd-19cb24ea-0fd2-4f52-8607-478da2cdb898

Rehman NNMA, \& Dixit PP. Influence of light wavelengths, light intensity, temperature, and $\mathrm{pH}$ on biosynthesis of extracellular and intracellular pigment and biomass of Pseudomonas aeruginosa NR1. Journal of King Saud University Science.

doi: 10.1016/j.jksus.2019.01.004

Richards FJ. A flexible growth function for empirical use. Journal of experimental Botany, 10(2), 290-301, 1959.

doi: $10.1093 / \mathrm{jxb} / 10.2 .290$

Richmond A. Handbook of microalgal culture: Biotechnology and applied phycology. Ames: Blackwell publishing. 2004.

Rivera-González MV, Gómez-Gómez L, \& Cubillos-Hinojosa JG. Effect of humic acids on the growth and the biochemical composition of Arthrospira platensis. Revista Colombiana de Biotecnología, 19(1), 71-81, 2017.

doi: $10.15446 /$ rev.colomb.biote.v19n1.58316

Ryu BG, Kim J, Han JI, \& Yang JW. Feasibility of using a microalgalbacterial consortium for treatment of toxic coke wastewater with concomitant production of microbial lipids. Bioresource Technology, 225, 58-66, 2017.

doi: 10.1016/j.biortech.2016.11.029

Sanmartín P, Vázquez-Nion D, Arines J, Cabo-Domínguez L, \& Prieto B. Controlling growth and colour of phototrophs by using simple and inexpensive coloured lighting: A preliminary study in the Light4Heritage project towards future strategies for outdoor illumination. International Biodeterioration and Biodegradation, 122, 107-115, 2017.

doi: 10.1016/j.ibiod.2017.05.003

Santiesteban-López N, López-Malo A. Descripción e importancia de algunos modelos predictivos utilizados como herramienta para la conservación de alimentos. Temas Selectos de Ingeniería de Alimentos, 2 (2): 14-26, 2008. 
Retrieved from

https:/ / www.udlap.mx/WP/tsia/files/No2-Vol-2/TSIA-2(2)Santiesteban-Lopez-et-al-2008a.pdf

Schuurman R, Matthijs J, \& Hellingwerf K. Transition from exponential to linear photoautotrophic growth changes the physiology of Synechocystis sp. PCC 6803. Photosynthesis research, 132(1), 69-82. 2017.

doi: $10.1007 /$ s11120-016-0329-8

Shalaby EA, Atta MB, Sleem IA, Mohamed MA, Lightfoot DA, \& El-Shemy HA. Cytotoxicity, antioxidant and antiviral potential of aqueous extract from Nostoc muscorum cultivated in various inexpensive media. Waste and Biomass Valorization, 10(5), 1419-1431, 2019.

doi: 10.1007/s12649-017-0188-3

Shukla M, Tabassum R, Singh R, \& Dhar DW. Influence of light intensity, temperature and $\mathrm{CO}_{2}$ concentration on growth and lipids in green algae and cyanobacteria. Indian Journal of experimental biology, 54, 482-487, 2016.

Retrieved from

http://nopr.niscair.res.in/bitstream/123456789/34750/1/ IJEB $\% 2054 \% 287 \% 29 \% 20482-487 . p d f$

Silva APR, Longhi DA, Dalcanton F, Aragão GMF. Modelling the growth of lactic acid bacteria at different temperatures. Brazilian archives of biology and technology, 61: e18160159, 2018.

doi: 10.1590/1678-4324-2018160159

Singh NK, Sonani RR, Rastogi RP, \& Madamwar D. The phycobilisomes: an early requisite for effcient photosynthesis in cyanobacteria. EXCLI journal, 14, 268, 2015.

doi: 10.17179/excli2014-723

Singh RS, Walia AK, KhattarJS, Singh DP, \& Kennedy JF. Cyanobacterial lectins characteristics and their role as antiviral agents. International Journal of Biological Macromolecules, 102, 475-496, 2017.

doi: 10.1016/j.ijbiomac.2017.04.041

Singh S, \& Singh P. Effect of temperature and light on the growth of algae species: a review. Renewable and Sustainable Energy Reviews, 50, 431-444, 2015.

doi: 10.1016/j.rser.2015.05.024 
Sinha RP, Ambasht NK, Sinha JP, \& Ha“der DP. Wavelengthdependent induction of a mycosporine-like amino acid in a ricefield cyanobacterium, Nostoc commune: role of inhibitors and salt stress. Photochemical and Photobiological Sciences, 2, 171-6, 2003.

doi: $10.1039 / \mathrm{b} 204167 \mathrm{~g}$

Solhaug KA, Xie L, Gauslaa Y. Unequal allocation of excitation energy between photosystem II and I reduces cyanolichen photosynthesis in blue light. Plant and Cell Physiology, 55: 1404-1414, 2014.

doi: $10.1093 / \mathrm{pcp} / \mathrm{pcu} 065$

Supriyanto, Noguchi R, Ahamed T, Rani DS, Sakurai K, Nasution MA, Wibawa DS, Demura M, \& Watanabe MM. Artificial neural networks model for estimating growth of polyculture microalgae in an open raceway pond. Biosystems Engineering, 177, 122-129, 2019.

doi: 10.1016/j.biosystemseng.2018.10.002

Swinnen IAM, Bernaerts K, Dens EJ, Geeraerd AH, \& Van Impe JF. Predictive modelling of the microbial lag phase: a review. International journal of food microbiology, 94(2), 137-159. 2004.

doi: 10.1016/j.ijfoodmicro.2004.01.006

Teo CL, Atta M, Bukhari A, Taisir M, Yusuf AM, \& Idris A. 2014. Enhancing growth and lipid production of marine microalgae for biodiesel production via the use of different LED wavelengths. Bioresource technology, 162, 38-44.

doi: 10.1016/j.biortech.2014.03.113

Tevatia R, Demirel Y, Blum P. Kinetic modeling of photoautotropic growth and neutral lipid accumulation in terms of ammonium concentration in Chlamydomonas reinhardtii. Bioresource Technology, 119: 419-424, 2012.

doi: 10.1016/j.biortech.2012.05.124

Tiwari ON, Devi WI, Silvia C, Devi AT, Oinam G, Singh OA, Singh KO, Indrama T, Sharma AS, Khangembam R, Shamjetshaban M, Miranda L, \& Prasanna R. Modula-tion of phycobiliprotein production in Nostoc muscorum through culture manipulation. Journal of Applied Biology \& Biotechnology, 3(04), 011-016, 2015.

doi: $10.7324 / \mathrm{JABB} .2015 .3403$ 
Tóth TN, Chukhutsina V, Domonkos I, Knoppová J, Komenda J, Kis M, Gombos ZJB. Carotenoids are essential for the assembly of cyanobacterial photosynthetic complexes. Biochimica et Biophysica Acta (BBA)-Bioenergetics, 1847(10), 1153-1165, 2015.

doi: 10.1016/j.bbabio.2015.05.020

Trejos VM, Alzate JF, Garcia MÁG. Descripción matemática y análisis de estabilidad de procesos fermentativos, text, 76 (158): 111-121, 2009.

Retrieved from https:/ / www.redalyc.org/pdf/496/49612069012.pdf

Vanegas DM, Ramírez ME. Correlación del crecimiento de Pseudomonas fluorescens en la producción de polihidroxialcanoatos de cadena media $\left(\mathrm{PHA}_{\mathrm{MCL}}\right)$ mediante modelos primarios de Gompertz, Logístico y Baranyi.Información tecnológica, 27 (2): 87-96, 2016.

doi: 10.4067/S0718-07642016000200011

Xiong S, Fan J, \& Kitazato K. The antiviral protein cyanovirin-N: the current state of its production and applications. Applied Microbiology and Biotechnology, 86, 805-812, 2010.

doi: 10.1007/s00253-010-2470-1

Xu L, Yong H, Tu X, Wanga Q, \& Fan J. Physiological and proteomic analysis of Nostoc flagelliforme in response to alkaline $\mathrm{pH}$ shift for polysaccharide accumulation. Algal Research, 39, 101444, 2019 .

doi: 10.1016/j.algal.2019.101444

Yang YW, Yin YC, Li ZK, Huang D, Shang JL, Chen M, \& Qiu BS. Orange and red carotenoid proteins are involved in the adaptation of the terrestrial cyanobacterium Nostoc agelliforme to desiccation. Photosynthesis Research, 140 (1), 103-113, 2019.

doi: 10.1007/s11120-019-00629-6

You Z, Xu H, Zhang S, Kim H, Chiang PC, Yun W, Zhang L, He M. Comparison of petroleum hydrocarbons degradation by Klebsiella pneumoniae and Pseudomonas aeruginosa. Applied Sciences, 8: 2551, 2018.

doi: $10.3390 / \operatorname{app} 8122551$ 
Zhao X, Ma R, Liu X, Ho SH, Xie Y, \& Chen J. Strategies related to light quality and temperature to improve lutein production of marine microalga Cblamydomonas sp. Bioprocess and Biosystems Engineering, 42 (3), 435-443, 2019.

doi: 10.1007/s00449-018-2047-4

Znad H, Al Ketife AM, \& Judd S. Enhancement of $\mathrm{CO}_{2}$ biofixation and lipid production by Chlorella vulgaris using coloured polypropylene film. Environmental Technology, 1-7, 2018.

doi: 10.1080/09593330.2018.1437778

Zwietering MH, Jongenburger I, Rombouts FM, \& Van't Riet K. Modeling of the bacterial growth curve. Applied and environmental microbiology, 56(6), 1875-1881, 1990.

doi: 0099-2240/90/061875-07\$02.00/0

\section{Modelamiento de los efectos de la longitud de onda de la luz sobre el crecimiento de Nostoc ellipsosporum}

Resumen: Los modelos matemáticos proveen información sobre las dinámicas poblacionales bajo diferentes condiciones. En el presente estudio, se evaluaron cuatro modelos (Baranyi-Roberts, Gompertz Modificado, Logístico Modificado y Richards) y se emplearon para describir la cinética de crecimiento de Nostoc ellipsosporum con diferentes longitudes de onda de luz. N. ellipsosporum creció en medio líquido BG-11 por 9 días, usando un fotoperiodo de 12 horas y los siguientes tratamientos: luz blanca $(400-800 \mathrm{~nm})$, luz roja $(650-800 \mathrm{~nm})$, luz amarilla (550-580 nm) y luz azul (460-480 nm). Cada experimento se llevó a cabo por triplicado. La densidad óptica (OD) se midió en los días 1, 3, 5, 7 y 9 usando un espectrofotómetro a $650 \mathrm{~nm}$. El máximo crecimiento celular se obtuvo con la longitud de onda de la luz blanca $\left(O D_{650}: 0.090 \pm 0.008\right)$, seguido de la luz amarilla $\left(O D_{650}: 0.057 \pm 0.004\right)$. Por el contrario, la luz azul mostró un marcado efecto inhibitorio en el crecimiento de $N$. ellipsosporum $\left(O D_{650}: 0.009 \pm 0.001\right)$. Los resultados revelaron que el modelo Baranyi-Roberts se ajustó mejor a los datos experimentales de crecimiento de $N$. ellipsosporum en los cuatro tratamientos. Los hallazgos de este estudio de modelación se pueden usar en diversas aplicaciones biotecnológicas que requieran la producción de $N$. ellipsosporum y sus bioproductos.

Palabras clave: cianobacterias; luz; modelo matemático; crecimiento microbiano. 


\section{Modelamento dos efeitos da longitude de onda da luz sobre o crescimento de Nostoc ellipsosporum}

Resumo: Os modelos matemáticos dao informações sobre as dinâmicas populacionais sob diferentes condições. No presente estudo, avaliaramse quatro modelos (Baranyi-Roberts, Gompertz Modificado, Logístico Modificado y Richards) e foram aplicados para descrever a cinética de crescimento de Nostoc ellipsosporum com diferentes longitudes de onda de luz. N. ellipsosporum cresceu em meio líquido BG-11 por 9 dias, usando um fotoperíodo de 12 horas e os seguintes tratamentos: luz branca (400-800 nm), luz vermelha (650-800 nm), luz amarela (550-580 nm) e luz azul (460-480 nm). Cada experimento se realizou por triplicado. A densidade óptica (OD) foi medida nos dias 1, 3, 5, 7 e 9, usando um espectrofotômetro a $650 \mathrm{~nm}$. O máximo crescimento celular foi obtido sob luz branca $\left(O D_{650}: 0.090 \pm 0.008\right)$, seguido de luz amarela $\left(O D_{650}: 0.057 \pm 0.004\right)$. Ao contrário, a luz azul mostrou um marcado efeito de inibição no crescimento de $N$. ellipsosporum $\left(O D_{650}: 0.009 \pm 0.001\right)$. Os resultados revelaram que o modelo Baranyi-Roberts se ajustou melhor aos dados experimentais de crescimento de $N$. ellipsosporum nos quatro tratamentos. As descobertas de este estudo de modelação podem ser usadas em diversas aplicações biotecnológicas que requeram a produção de $N$. ellipsosporum e seus bioprodutos.

Palavras-chave: cianobactérias; luz; modelo matemático; crescimento microbiano. 


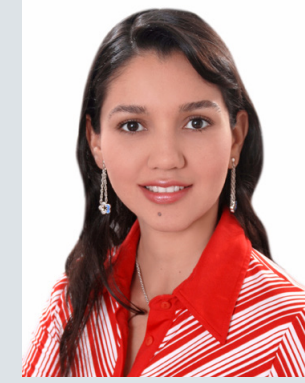

\section{Martha Lucia Ortiz-Moreno}

Was born in Villavicencio, she is a Biologist graduated with a master in Microbiology from Universidad Nacional de Colombia. She has a degree in University Teaching from Escuela Superior de Administración Pública, and a PhD in Ecology and Natural Resources from Universidad Federal de São Carlos (Brazil). She has several papers on applied microbiology.

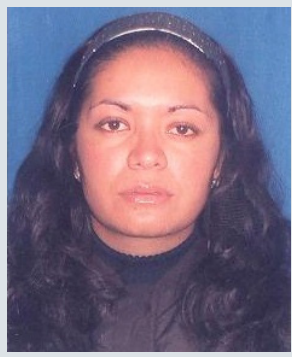

\section{Jaleydi Cárdenas-Poblador}

Was born in Bogota, she is a Mathematician graduated with a master in Mathematical Science from Universidad Nacional de Colombia. Her studies focus on mathematical modeling for Biological and Environmental Sciences applications.

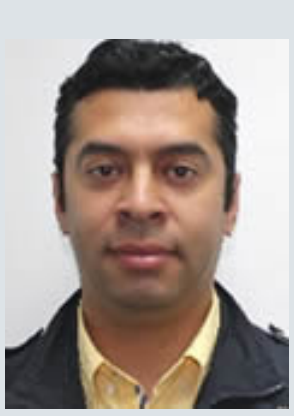

\section{Julián Agredo}

Was born in Cali, he is a Mathematician graduated from Universidad Nacional de Colombia, with a master degree in Mathematics from Universidad Católica de Chile and a doctorate in Sciences with a mention in mathematics from Universidad de Chile. His studies focus on Real and Complex Analysis, Probability, Stochastic processes, Stochastic analysis, mathematical physics and its applications.

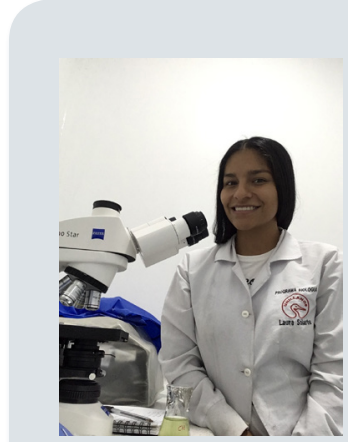

\section{Laura Vanessa Solarte-Murillo}

She is a Biologist student from Universidad de los Llanos. She is a part of BIORINOQUIA investigation group from the same University, and has research experience in aquaculture biotechnology and genetics. 